\title{
Korelasi Pleural Effusion Index dengan Jarak Interpleura secara Ultrasonografi pada Demam Berdarah Dengue Anak
}

\author{
Arum Kusumaningtias, MMDEAH Hapsari, ${ }^{*}$ Bambang Satoto ** \\ *Departemen Ilmu Kesehatan Anak, ${ }^{* *}$ Departemen Ilmu Radiologi Fakultas Kedokteran Universitas \\ Diponegoro/ Rumah Sakit Dr. Kariadi, Semarang
}

\begin{abstract}
Latar belakang. Infeksi dengue merupakan infeksi virus tropis yang paling penting saat ini. Pleural effusion index (PEI) digunakan sebagai prediktor derajat DBD, berperan dalam menentukan skor kebocoran vaskular (SKV), dan merupakan faktor risiko terjadinya mortalitas pada DSS. Melalui pemeriksaan foto toraks RLD, pengukuran PEI menimbulkan efek radiasi dan sulit dilakukan pada pasien yang tidak dapat dimobilisasi. Pemeriksaan ultrasonografi toraks tidak menimbulkan efek radiasi dan dapat mengetahui estimasi volume efusi pleura dengan mengukur jarak interpleura pada posisi supine.

Tujuan. Menganalisis korelasi pleural effusion index dengan jarak interpleura secara ultrasonografi pada demam berdarah dengue anak.

Metode. Desain penelitian belah lintang menggunakan 14 pasien DBD anak selama bulan Juli sampai dengan November 2014, dilakukan di RSUD Dr. Kariadi Semarang, dan subjek berusia 10 bulan-12 tahun. Pada hari kelima demam dilakukan pemeriksaan foto toraks RLD, dilanjutkan pemeriksaan ultrasonografi toraks.

Hasil. Uji korelasi Rank Spearman memperlihatkan PEI berkorelasi positif sedang dengan jarak interpleura secara sonografi $(\mathrm{p}=0,014 ;$ rho $=0,639)$.

Kesimpulan. Terdapat korelasi bermakna antara nilai PEI dengan jarak interpleura secara sonografi pada pasien DBD anak. Sari Pediatri 2015;16(5):337-41.
\end{abstract}

Kata kunci: DBD, PEI, jarak interpleura secara sonografi

I

nfeksi dengue merupakan infeksi virus tropis pada manusia yang paling penting saat ini. Pada 10 sampai 15 tahun terakhir, infeksi dengue menduduki peringkat ketiga sebagai penyebab terbanyak perawatan dan kematian pasien anak di

Alamat korespondensi:

Dr. MMDEAH Hapsari, SpA(K). Departemen Ilmu Kesehatan Anak Fakultas Kedokteran Universitas Diponegoro/ Rumah Sakit dr Kariadi Semarang
Asia Tenggara. Infeksi dengue disebabkan oleh virus family Flaviviridae, genus Flavivirus yang mempunyai 4 serotipe, yaitu Den 1, Den 2, Den 3, dan Den 4. Infeksi simtomatik terbagi menjadi undifferentiated fever, demam dengue tanpa perdarahan, demam dengue disertai perdarahan, demam berdarah dengue tanpa syok, dan demam berdarah dengue disertai syok (sindrom syok dengue). ${ }^{1}$

Perjalanan DBD dibagi menjadi 3 fase, yaitu fase febris, kritis, dan konvalesen. Kebocoran plasma 
dan hemokonsentrasi merupakan proses patofisiologi utama. Kebocoran plasma bersifat unik karena bersifat selektif, yaitu pada rongga pleura dan peritoneum dalam waktu 24-48 jam setelah demam turun. ${ }^{2-4}$

Efusi pleura merupakan salah satu tanda kebocoran plasma pada DBD. Pleural effusion index adalah perbandingan antara tebal maksimal efusi pleura dan lebar maksimal hemitoraks yang didapatkan dari pemeriksaan foto toraks posisi RLD. Penilaian pleural effusion index (PEI) dapat digunakan sebagai prediktor beratnya DBD, berperan dalam menentukan skor kebocoran vaskular (SKV), dan merupakan faktor risiko terjadinya mortalitas pada DSS. Pengukuran PEI menimbulkan efek radiasi dan sulit dilakukan pada pasien yang tidak dapat dimobilisasi. ${ }^{5-7}$

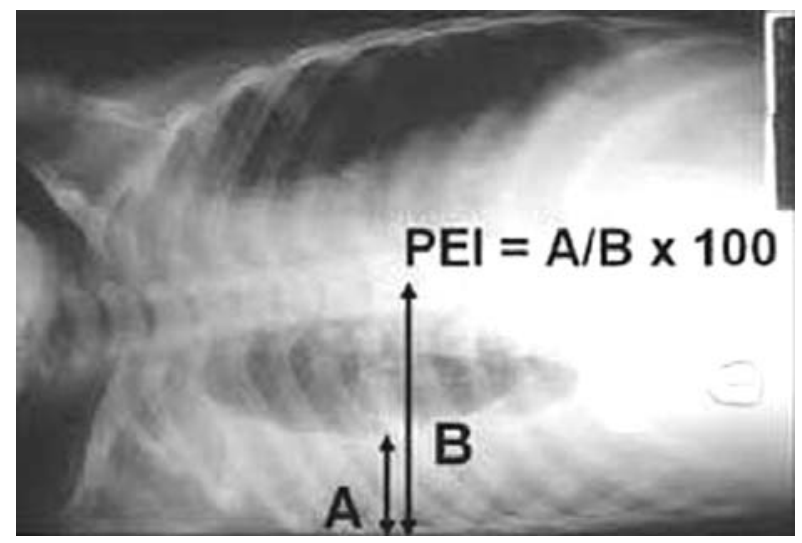

Gambar 1. Cara mengukur nilai PEI8

Pemeriksaan ultrasonografi toraks mempunyai reliabilitas lebih baik untuk mendiagnosis efusi pleura, tidak menimbulkan efek radiasi, bersifat portable, dan dapat dilakukan pada pasien dengan posisi supine. Melalui pemeriksaan ultrasonografi juga dapat diketahui estimasi volume efusi pleura, salah satunya dengan mengukur jarak interpleura pada posisi supine.?

Melalui penelitian ini penulis ingin mengetahui korelasi antara nilai PEI dan jarak interpleura pada pasien efusi pleura. Penulis juga berharap hasil penelitian ini dapat menjadi masukan kepada klinisi terkait dengan pemilihan pemeriksaan penunjang untuk pasien DBD dengan efusi pleura.

\section{Metode}

Penelitian dilaksanakan di RSUP Dr. Kariadi, Semarang, pada bulan Juli hingga November 2014. Rancangan penelitian adalah analitik observasional dengan desain belah lintang. Populasi terjangkau sampel penelitian adalah pasien DBD anak yang dirawat di bangsal anak yang memenuhi kriteria. Kriteria inklusi adalah pasien dengan diagnosis DBD derajat I - III (WHO 1999) dan telah dilakukan pemeriksaan radiologi toraks posisi RLD dan dibaca oleh dokter radiologi. Kriteria eksklusi adalah orang tua pasien menolak mengikuti penelitian, tidak dapat dilakukan pemeriksaan ultrasonografi, dan dicurigai ada kelainan lain yang menyebabkan efusi pleura. Sampel penelitian dipilih berdasarkan metode consecutive sampling yaitu berdasarkan kedatangan pasien di rumah sakit.

\section{Pemeriksaan foto toraks RLD dan pengukuran PEI}

Pasien diperiksa pada posisi right lateral decubitus minimal selama 5 menit dengan tangan di ekstensi ke atas kepala. Gambar diambil saat fase ekspirasi. Pleural effusion index adalah perbandingan antara tebal maksimal efusi pleura dan lebar maksimal hemitoraks kanan pada pemeriksaan foto toraks posisi right lateral decubitus (RLD) dikalikan 100.

\section{Pemeriksaan ultrasonografi dan pengukuran jarak interpleura}

Pasien diperiksa pada posisi supine. Probe diletakkan posisi transversal di spatium intercostal sisi laterodorsal dada tepat di sebelah kranial basis paru. Diukur jarak perpendicular terlebar antara pleura viseralis dan pleura parietalis dinding posterior dada (dalam millimeter). Probe yang digunakan adalah probe linear dengan rentang frekuensi $5-15 \mathrm{MHz}$. Pemeriksaan ultrasonografi dilakukan oleh peneliti di instalasi radiologi segera setelah pemeriksaan foto toraks RLD selesai dilakukan. Jarak antara pleura parietalis dan pleura viseralis terbesar pada pemeriksaan ultrasonografi toraks posisi supine dalam satuan millimeter $(\mathrm{mm})$.

Data dianalisis menggunakan korelasi non-parametric menggunakan uji korelasi Rank Spearman. Korelasi dianggap bermakna jika memiliki nilai $\mathrm{p}<0,05$ dengan kekuatan korelasi mendekati 1 dianggap makin kuat.

\section{Hasil}

Pada periode penelitian didapatkan 14 sampel yang memenuhi kriteria inklusi. Usia subjek termuda adalah 10 bulan dan tertua 12 tahun. Sepuluh subjek 
berusia lebih dari 6 tahun. Laki-laki lebih banyak dibandingkan perempuan. Berdasarkan kriteria WHO 1997, terdapat 4 kasus demam dengue, 7 kasus DBD derajat 1 , dan 3 derajat 2 .

Efusi pleura terdeteksi pada dua belas sampel, baik dengan pemeriksaan foto toraks RLD maupun pemeriksaan ultrasonografi toraks. Pada pemeriksaan foto toraks RLD, efusi pleura terdeteksi pada 9 subjek. Pada pemeriksaan ultrasonografi toraks saja, efusi pleura terdeteksi pada 10 subjek. Terdapat 2 subjek efusi pleura dapat dideteksi dengan pemeriksaan foto toraks RLD, tetapi tidak terdeteksi dengan pemeriksaan ultrasonografi. Terdapat 3 subjek dengan efusi pleura yang terdeteksi dengan pemeriksaan ultrasonografi, tetapi tidak terdeteksi dengan pemeriksaan foto toraks RLD. Nilai rata-rata PEI 4,6 $\pm 1,31$, sedangkan nilai rerata jarak interpleura secara ultrasonografi 4,5 $\pm 1,30$ $\mathrm{mm}$. Frekuensi efusi pleura pada pemeriksaan foto toraks RLD terdapat 9 dan ultrasonografi toraks 10.

Secara ultrasonografi, nilai tertinggi PEI 13,95 (rerata SB 4,6 $\pm 1,31$ ) dan jarak interpleura $16,30 \mathrm{~mm}$ (rerata SB 4,5 $\pm 1,30$ ) $\mathrm{mm}$.

Hemokonsentrasi ditentukan dari selisih nilai hematokrit tertinggi dan terendah selama perawatan di rumah sakit. Peningkatan hematokrit dialami 13 subjek dengan peningkatan yang bervariasi. Peningkatan hematokrit kemudian dikelompokkan menjadi $<5 \%$, 5\%-10\%, 10\%-15\%, dan >15\%.

Berdasarkan uji Shapiro Wilk, data jarak interpleura secara ultrasonografi dan data PEI mempunyai distribusi tidak normal. Data tersebut dianalisis secara non-parametrik dengan uji korelasi Spearman. Korelasi PEI dengan jarak interpleura secara ultrasonografi adalah 0,639 dengan $\mathrm{p}=0,014(\mathrm{p}=<0,05)$

\begin{tabular}{lcccc}
\multicolumn{2}{l}{ Tabel 1. Karakteristik subjek penelitian $(\mathrm{n}=14)$} \\
\cline { 2 - 4 } Karakteristik pasien & \multicolumn{3}{c}{ Frekuensi } & \multicolumn{1}{c}{ Total } \\
\cline { 2 - 4 } & DD & DBD derajat 1 & DBD derajat 2 & \\
\hline Usia (tahun) & 2 & 1 & 1 & 4 \\
$\quad<6$ & 2 & 6 & 2 & 10 \\
$\quad>6$ & 3 & 3 & 3 & \\
Jenis kelamin & 1 & 4 & 0 & 5 \\
$\quad$ Laki-laki & 4 & 7 & 3 & 14 \\
$\quad$ Perempuan & & & & \\
\hline Total & & & & \\
\hline
\end{tabular}

Tabel 2. Tabel silang temuan efusi pleura pemeriksaan foto toraks RLD dan ultrasonografi toraks

\begin{tabular}{lcccc}
\hline Variabel & \multicolumn{2}{c}{ Ultrasonografi toraks } & Total \\
\cline { 2 - 4 } & & $\begin{array}{c}\text { Tidak terdeteksi efusi } \\
\text { pleura }\end{array}$ & $\begin{array}{c}\text { Terdeteksi efusi } \\
\text { pleura }\end{array}$ & \\
\hline Foto toraks RLD & Tidak terdeteksi efusi pleura & 2 & 3 & 5 \\
& Terdeteksi efusi pleura & 2 & 7 & 9 \\
\hline Total & & 4 & 10 & 14 \\
\hline
\end{tabular}

Tabel 3. Tabel silang persentase peningkatan hematokrit dengan temuan efusi pleura

\begin{tabular}{llccc}
\hline Variabel & & \multicolumn{2}{c}{ Foto toraks RLD dan ultrasonografi toraks } & Total \\
\cline { 3 - 4 } & & $\begin{array}{c}\text { Tidak terdeteksi efusi } \\
\text { pleura }\end{array}$ & Terdeteksi efusi pleura & \\
\hline Persentase & Tidak ada peningkatan hematokrit & 1 & 0 & 1 \\
peningkatan & Hematokrit meningkat $<5$ & 1 & 5 & 6 \\
hematokrit & Hematokrit meningkat $5-10$ & 0 & 3 & 3 \\
& Hematokrit meningkat $>15$ & 0 & 4 & 4 \\
\hline Total & & 2 & 12 & 14 \\
\hline
\end{tabular}




\section{Pembahasan}

Empat belas pasien infeksi dengue yang didiagnosis berdasarkan kriteria WHO 1999 dan pemeriksaan serologi, berusia 10 bulan sampai 12 tahun, dengan manifestasi infeksi dengue berupa DD, DBD grade 1 dan 2. Sepuluh berada pada usia lebih dari 6 tahun, usia $>6$ tahun terbanyak DBD derajat 1 . Beberapa penelitian menyebutkan usia $>6$ tahun lebih berisiko terjadi DBD dan DSS. ${ }^{10}$ Laki-laki lebih banyak, sesuai dengan penelitian oleh Hartoyo. ${ }^{11}$

Pemeriksaan foto toraks RLD dilakukan pada demam hari kelima. Pemeriksaan foto toraks RLD mendeteksi efusi pleura pada 9/14. Rentang nilai PEI adalah 0 sampai 13,95 . Nilai rata-rata PEI 4,6 dengan $\mathrm{SB} \pm 1,31$.

Pada pemeriksaan ultrasonografi toraks, efusi pleura tampak sebagai area anekoik di antara dua garis ekogenik (pleura parietal dan visceral), sickle shape, terbanyak pada bagian dorsal, dan mengalami perubahan bentuk dan ukuran akibat gerakan respirasi. Temuan tersebut sesuai dengan penelitian Eibenberger $\mathrm{dkk},{ }^{8}$ yaitu pada posisi supine, efusi pleura terkumpul paling banyak pada bagian dorsal dengan bentuk sickle shaped.

Efusi pleura tampak lebih jelas pada fase ekspirasi sehingga jarak interpleura diambil pada fase ekspirasi. Temuan tersebut sesuai dengan deskripsi Koncijancic $\mathrm{dkk},{ }^{12}$ yaitu pada pemeriksaan ultrasonografi toraks, efusi pleura (posisi decubitus) fase ekspirasi tampak lebih jelas dibanding fase inspirasi. Pemeriksaan ultrasonografi toraks mendeteksi efusi pleura pada 10/14 subjek. Rentang nilai jarak interpleura adalah 0 sampai $16,3 \mathrm{~mm}$, nilai rata-rata jarak interpleura adalah $4,5 \pm 1,30 \mathrm{~mm}$.

Pemeriksaan ultrasonografi toraks mendeteksi efusi pleura lebih banyak dibandingkan pemeriksaan foto toraks RLD. Pemeriksaan ultrasonografi toraks mendeteksi efusi pleura pada $10 / 14$, sedangkan foto toraks RLD mendeteksi 9/14 subjek. Dari 10 efusi pleura yang terdeteksi dengan pemeriksaan ultrasonografi toraks, 3 di antaranya tidak terdeteksi melalui pemeriksaan foto toraks RLD. Temuan tersebut sesuai dengan penelitian Balasubramanian $\mathrm{dkk},{ }^{13}$ yaitu pemeriksaan ultrasonografi toraks mempunyai sensitivitas lebih tinggi dibandingkan pemeriksaan foto toraks dalam mendeteksi efusi pleura pada pasien DBD.

Sebaliknya, dari efusi pleura yang terdeteksi dengan pemeriksaan foto toraks RLD, dua di antaranya tidak terdeteksi melalui pemeriksaan ultrasonografi. Temuan tersebut sesuai dengan penelitian Srikiatkhachorn $\mathrm{dkk}^{14}$ yang menemukan pemeriksaan foto toraks RLD lebih sensitif dibandingkan pemeriksaan ultrasonografi toraks dalam mendeteksi efusi pleura. Hal tersebut mungkin terjadi karena perbedaan bentuk kavum toraks. Apabila sirkumferensial posterior kavum toraks lebih besar dari sirkumferensial lateral, posisi supine cairan efusi terdistribusi pada area yang lebih besar dan tampak lebih sedikit. ${ }^{13}$

Peningkatan hematokrit adalah salah satu tanda kebocoran plasma. Badan kesehatan dunia WHO, pada tahun 1999, menggunakan peningkatan hematokrit $>20 \%$ sebagai kriteria diagnostik DBD. Pada penelitian ini, ada tidaknya peningkatan hematokrit ditentukan dari selisih nilai hematokrit tertinggi dan terendah yang diambil selama pasien dirawat di rumah sakit, kemudian dikelompokkan berdasarkan persentase peningkatan hematokrit. Peningkatan hematokrit $>20 \%$ tidak digunakan karena tidak ada data nilai hematokrit sebelum pasien mengalami demam.

Analisis non parametrik dengan uji korelasi Rank Spearman, didapatkan nilai $\mathrm{p}=0,014$ dan nilai koefisien korelasi 0,639 dengan arah positif. Nilai $\mathrm{p}<0,05$ menunjukkan korelasi yang bermakna. Nilai koefisien korelasi 0,639 menunjukkan kekuatan korelasi adalah sedang. Arah korelasi positif menunjukkan peningkatan nilai PEI sebanding dengan peningkatan jarak interpleura secara sonografi, dan sebaliknya. Temuan tersebut sesuai dengan penelitian Srikiatkhachorn $\mathrm{dkk}^{14}$ yang menyebutkan terdapat korelasi antara ukuran efusi pleura pada pemeriksaan ultrasonografi dengan PEI. Penelitian ini berbeda dengan penelitian Srikiatkhachorn karena pemeriksaan ultrasonografi dilakukan pada posisi erect dan jarak interpleura yang diukur adalah jarak vertikal antara dome diafragma dan basis paru.

\section{Kesimpulan}

Terdapat korelasi bermakna antara nilai PEI dengan jarak interpleura secara sonografi pada pasien DBD anak.

\section{Daftar pustaka}

1. WHO. Guidelines for treatment of dengue fever/dengue hemorrhagic fever in small hospitals. New Delhi: WHO 
Regional Officer for South East Asia;1999.

2. Withayawomwong P. Dengue hemorrhagic fever in infancy at Petchabun Hospital, Thailand. Southeast Asian J Trop Med Public Health 2001;32:481-7.

3. WHO. Comprehensive guidelines for prevention and control of dengue and dengue hemorrhagic fever. New Delhi: WHO Regional Officer for South East Asia;2011.

4. Ashis SK, Shibendu G. Clinico-pathological profile in the infants and children in dengue 2012 epidemic, Kolkata. Int J Med Res Health Sci 2014;3:59-64.

5. Setiati TE, Retnaningsih A, Supriatna M, Soemantri A. Skor kebocoran vaskuler sebagai prediktor awal syok pada demam berdarah dengue. J Ked Brawijaya 2005;21:16-21.

6. Cahyaningrum JMH. Indeks efusi pleura sebagai prediktor sindrom syok dengue pada anak di RSUD Dr. Moewardi Surakarta. J Ked Indon 2009;1:32-9.

7. Hawarini N, Kosim MS, Supriatna M, Istanti Y, Sudijanto E. The relationship between pleural effusion index and mortality in children with dengue shock syndrome. Paediatr Indones 2012;52:239-42.

8. Eibenberger KL, Dock WI, Ammann ME, Dorffner R, Hormann MF, Grabenwoger F. Quantification of pleural effusions : sonography versus radiography. Radiology 1994; 191:681-4.

9. Reuss J. The Pleura. Dalam: Mathis G, penyunting. Chest sonography. Edisi ke-2. Austria: Springer;2008.h.25-9.

10. Pongpan S, Wisitwong A, Tawichasri C, Patumanond J. Prognostic indicators for dengue infection severity. Int J Clin Pediatr 2013;2:12-8.

11. Hartoyo E. Spektrum klinis demam berdarah dengue pada anak. Sari Pediatri 2008; 10:45-50.

12. Potts JA, Gibbons RV, Rothman AL, Srikiatkhachorn A, Thomas SJ, Supradish P. dkk. Prediction of dengue disease severity among pediatric Thai patients using early clinical laboratory indicators. Prevent Behav Med 2010;4:1-7.

13. Balasubramanian S, Janakiraman L, Kumar SS, Muralinath S, Shivbalan S. A reappraisal of the criteria to diagnose plasma leakage in dengue hemorrhagic fever. Indian Pediatrics 2006;43:334-9.

14. Srikiatkhachorn A, Krautrachue A, Ratanaprakarn W, Wongtapradit L, Nithipanya N, dkk. Natural history of plasma leakage in dengue hemorrhagic fever: a serial ultrasonographic study. Pediatr Infect Dis J 2007;26:28390. 